\title{
CURRENT ECONOMY AND ENVIRONMENT OF KAZAKHSTAN IN 1995
}

\author{
Tsuneo TSUKATANI \\ (Kyoto University) \\ and \\ Umirzak M. SULTANGAZIN \\ (Kazakh National Academy of Sciences)
}

[Key words: Kazakhstan; The Aral Sea; Semipalatinsk; Caspian Sea; Environment]

\section{Introduction}

With a territory of 2.7 million $\mathrm{km}^{2}$ and a border line of $11,292 \mathrm{~km}$, Kazakhstan is the second largest country in the Commonwealth of Independent States after the Russia Federation. It benefits from a strategic geographic location and from its significant potential of natural resources. In terms of mineral resources, it is one of the richest countries in the world. With appropriate incentive to modernization, these mineral resources could form the basis of a modern production system. For example, iron ore reserves total 16,600 million tons, nearly $8 \%$ of world reserves, of which nearly 8,800 million tons have been evaluated with a view to production, for manganese ore 45.8 million tons and for chromic iron 399.1 million tons respectively. Kazakhstan has 2.7 billion tons of proven oil reserves, though the number of functioning wells has fallen to 368 in 1994 from 604 in 1991. As of 1994, Kazakhstan produces 20 million tons of oil and gas condensate, and by the year 2000 hopes are high to boost oil production to 45 million tons annually. Vast areas of agricultural land, in spite of its poor state, permit Kazakhstan to harvest on average between 20-30 million 
tons of grain every year. Following the transformation of the agricultural sector, using modern technology, we would anticipate that Kazakhstan will become a net food exporter. In addition, Kazakhstan has much of excellent human resource with well educated, scientifically qualified and technically highly skilled workforce. Unfortunately, the lack of a commercial orientation in many of the existing scientific and technical institutions represents a significant constraint to the effective utilization of Kazakhstan's natural and human resource in future. The economic and environmental changes that are likely to take place over the coming years are discussed in this paper.

In the development of any object of national economy, it is possible to differentiate between surface and underlying factors. For example, irrigation development for agricultural purpose increased the production and gave rise to sharp increases in GNP during the last few decades. But significant factors underlying in the process were overlooked and ignored for years. With time the development overturned all the expectations. The death of the Aral Sea is a poignant example. The task of the science is to reveal these underlying processes and to provide qualitative and quantitative forecasts of the consequences of large economic and ecological projects and to promote more environmentally sustainable forms of the development. The comprehensive analysis of complicated economic systems and decision-making in the transition to market economy cannot be undertaken without extensive application of economic theory and mathematical modeling. Therefore, we attempt to construct some econometric and mathematical models of Kazakhstan economy that appears elsewhere'.

\section{Economic Situation in Kazakhstan}

Contemporary Kazakhstan is something of a contradiction. On one hand, as mentioned above, it is rich in terms of territory, natural and human resources. On the other, its industrial and infrastructural base is still underdeveloped. Past economic growth in Kazakhstan was tied to the industrial production system of the Soviet Union, through which it provided agricultural products and minerals.

1. U. Sultangain and T. Tsukatani: Modeling of Economy and Environment of Kazakhstan, KIER discussion Paper Series, No.416, March 1995. 
These primary industries represented a large part of GNP of Kazakhstan. During the communist regime, $85 \%$ of investment was directed toward the mining and raw material processing industries. As a result of this policy, present manufacturing and service sectors have a low share in the GNP. The situation has become even more difficult by the fact that current income from the sale of mining and agricultural products does not cover real expenditure in these sectors. Furthermore, tax receipts compose $31 \%$ of national revenue, while payments from the profits of state and private enterprises currently stands at only $14 \%^{2}$.

Russia and other former republics still exert considerable influence on the economy of Kazakhstan and vice versa. Industrial enterprises have close relation with those in Russia, Ukraine and other republics. For example, the main oil fields in the west of Kazakhstan delivered 75.5 million barrels of crude oil and 33.6 thousand barrels of oil products to Russia in 1993. Its own refineries mainly located in the east, however, received 61.846 million barrels of Russian Siberian crude oil and 18.724 million barrels of products that include gasoline, diesel, and furnace oil in the same year ${ }^{3}$. Consequently, the recent breakdown of political and economical relations between republics resulted in 1,400 insolvent enterprises in Kazakhstan.

The transition period is provoking new and complex issues with which the present Kazakh Government is trying to deal through the development of an independent economic policy. It involved for the first step pulling out of the ruble zone and introducing its own currency in November 1993. Second, the Government has approved priority to develop a program for oil and gas sectors including a project which involves laying oil pipeline from the Tengiz oil field to the Black Sea. Third, contracts have been signed with western companies such as Chevron, British Gas, Elf and others for the development of oil and gas deposits. However, at present, there still remain difficulties with the transport of oil and gas through the territories of neighboring countries. These difficulties, as well as obsolete equipment some of which date to $1950 \mathrm{~s}$ and inefficient bureaucratism, are slowing foreign currency and investment enter into Kazakhstan.

2. N. Nazarbayev: The Strategy of Resource Saving and the Transition to the Market Economy, Moscow, 1992. (in Russian)

3. J.P. Dorian et al.: Central Asia's Oil and Gas Pipeline Network: Current and Future Flows, Post-Soviet Geography 35, 7, 412-430, 1994. 
The basic policies for many former socialistic countries in the transition period to market economy include three items: 1) price and production liberalization from state control; 2) privatization of state property and establishment of infrastructure for the state and private sectors; and 3) macroeconomy stabilization and budget balancing through fostering financial transactions.

While strategies to realize above general policies vary from country to country, some of these measures, implemented by the Kazakh Government, have not yet brought good results. For example, we witness some negative economic trends. The basic infrastructure for a market economy is still not in place and the stock and capital markets barely exist. Though it is believed inside and outside of Kazakhstan that the main stimulus to revive the economy is currently only through foreign investment, yet the lack of favorable market conditions is hindering its further development. The current problem exists in the situation whereby the existing production system is being destroyed without the substitution of new ones. Domestic investments are constantly depreciating. The government is active but concrete programs developed on a scientific basis are lacking and the economic situation of the Republic remains critical.

The national income in 1994 is less than that of 1976 and the GNP declined by $31 \%$ and national income by $32 \%$ in 1994 compared with those of 1993. The degree of decreasing economic activity is presented in Table 1 with the main economical indicators. The level of inflation was high at 2,265\% in 1993 and at $1,259 \%$ in 1994 . This was linked mainly to the liberalization of the basic commodity prices and the government's monetary policy. Moreover, problems of the delayed payment for workers (the payment crisis) are serious barrier in the way of reform and economic stabilization. The army of the unemployed is growing and its number currently stands at about 150,000 and is expected to increase up to 500,000 in the near future, though the definition of unemployment differs from that of ILO.

One critical problem is the need for industrial diversification of the Kazakhstan economy and its efficiency improvement. It is therefore necessary to reallocate the optimal ratio between groups of production, particularly between mining and processing industries. Another problem is the determination of appropriate price for mining and agricultural products according to the demand from international market. One must then define what kind of goods and what 
Table 1 Decrease of the Economic Activity of Kazakhstan as compared to previous year in $\%$

\begin{tabular}{lcrrrc}
\hline & 1990 & 1991 & 1992 & 1993 & 1994 \\
\hline Gross domestic product & - & -11.8 & -13.0 & -12.9 & -25.4 \\
National income & -0.9 & -14.9 & -14.0 & -14.8 & - \\
Total industry volume & -0.8 & -0.9 & -13.8 & -16.1 & -28.5 \\
Volume of agri. prod & +7.0 & -10.0 & +0.8 & -9.8 & -21.2 \\
Investment & -2.9 & -11.0 & -47.0 & -30.0 & -31.1 \\
Traffic volume & -6.3 & -18.6 & -17.3 & -30.5 & - \\
\hline
\end{tabular}

+ symbol indicates increase as compared to previous year.

quantities should be produced in Kazakhstan. Accordingly it may be necessary to change the present governmental investment policy.

\section{Ecological Crisis in Kazakhstan and Perspectives on its Solution}

The vast territory and low population density of Kazakhstan well explain the irresponsible attitude of the past policy toward the natural environment. It was wrongly perceived that land and environment were infinite resources. The short- sighted policy of the Soviet administration resulted in the designation of many regions as military testing grounds. Furthermore, exploitative irrigation policy to support cotton production led to the contraction of the Aral Sea. Excessive ploughing also caused soil erosion and degradation of vast areas of Kazakhstan. Many regions consequently now face ecological catastrophe as shown in Figure 1 whose details are explained in the later section, particularly in the Aral, Caspian and the Central Kazakhstan regions and in the area of the Semipalatinsk nuclear test site. Though we will further continue this section with brief discussions of environmental issue in a number of key regions, we have to provide here some additional environmental information on general condition of Kazakhstan.

According to the results of continuous monitoring of temperature variations in different parts of Kazakhstan, every district of Kazakhstan shows a temperature increase over the last 30 years and, correspondingly, total climate aridization. This effect may reflect the impact of global warming creating an unfavorable background for the process of desertification resulting from technogenic activity.

The consequences of ecological stresses are reflected in human health 
conditions. An example from the survey by the Ministry of Public Health and Academy of Sciences shows high morbidity of the population along the River Irtysh and Buchtarminscoe Sea, the water of which has high concentration of heavy and non-ferrous metals and industrial sewage. A very unfavorable situation is also observed around the towns of Ust-Kamenogorsk, Leninogorsk, Zyrjanovsk, where, in addition to water pollution, air pollution is another very negative factor.

\section{The Arall Sea Region}

The Aral region is in a critical status, as a result of sharp decrease of water inflow from Syr Darya and Amu Darya rivers. The unwise policy of water usage led to the catastrophic drying of the Sea and, as a consequence, to the degradation of soil, vegetation, fauna and progressive aridization and desertification of adjacent territories. The influence of the Aral tragedy on global environment manifests itself even now, but it will be more critical particularly in the 21 st Century. Understanding the problems of the Aral Sea basin and the Aral itself requires consideration of the correlation between the problems of Central Asia and its geographic, natural, economic characteristics, also with regard to its social and economic development. In this area for a considerable period, cotton plants have occupied more than $50 \%$ of better irrigation land and half of the water resource were used for its irrigation. The Aral problems arose as a result of the irresponsible exploitation of water resource and increasing water consumption in the basin without effluent under the arid climate. Since 1966 onwards, half of the water resource $(63 \mathrm{~km} / y$ year; including underground water) have been distributed for the creation of national product and half allowed to inflow to the Aral Sea $\left(57 \mathrm{~km}^{3} / \mathrm{year}\right)$. After the well-known decision of Plenum of the Central Committee of Communist Party of Soviet Union on increasing production of cotton, all former policies for water use were sharply changed. The distribution of water and its connection with GNP are shown in Table 2. In that time some scientists including academician Gerasimov and others appealed against decision of the Party and they predicted the consequences of it, but without success.

Following the decision the irrigation and agriculture sectors grew up to 60 $\%$ of the GNP. As a result of the Soviet Union's economic policy and the low 
KAZAKHSTAN IN 1995

Table 2 Dynamics of Water Flow in the Aral Sea Basin

\begin{tabular}{lcccc}
\hline & year & 1960 & 1975 & 1990 \\
\hline GNP & $10^{6}$ Ruble & 16.1 & 50.6 & 74 \\
Industrial & $10^{6}$ Ruble & 6.6 & 23.8 & 17.0 \\
Agriculture & $10^{6}$ Ruble & 8.4 & 15.0 & 23.0 \\
Agricultural Area & $10^{6}$ hectare & 4.5 & 6.8 & 7.2 \\
\hline Population & $10^{6}$ & 14.2 & 24.3 & 30.4 \\
\hline Water Consumption & & & & \\
Industry and Public Utility & $\mathrm{km}^{3}$ & 2.0 & 5.2 & 7.0 \\
Irrigation & $\mathrm{km}^{3}$ & 61 & 80 & 91 \\
To abroad & $\mathrm{km}^{3}$ & 1.0 & 1.5 & 2.2 \\
To the Aral Sea & $\mathrm{km}^{3}$ & 47 & 24 & 9 \\
Loss of Water & $\mathrm{km}^{3}$ & 9.0 & 9.5 & 10.6 \\
\hline
\end{tabular}

power of water source $\sim 120 \mathrm{~km}^{3} /$ year.

level of then-existed agricultural technology, arose a social, economic and environmental crisis. Over 30 years, inflow into the Aral Sea dropped from 56 to $5-10 \mathrm{~km}^{3}$ per annum, the water level decreased by 17 meters, the Sea's surface decreased by $40 \%$ and water volume by $60 \%$. The water salinity mixed with chemicals has reached $25-30 \mathrm{~g} / \mathrm{litter}$, and when it first exceeded $20 \mathrm{~g} / \mathrm{litter}$ in 1984 arrived the death of all fish species. Mineralization of water in Syr Darya (previously fresh) reached $3 \mathrm{~g} /$ litter, 10 times of health standards. In the growing season, pollution of Syr Darya by pesticides reached 11.3 times of MPC (maximum permissible concentration), for nitrates 46 times of MPC, for DDT $0.26 \mathrm{mg} / \mathrm{kg}(\mathrm{MPC}=0 \mathrm{ppm})$. Concentration of DDT in water biocenoses amounted to $0.29 \mathrm{mg} / \mathrm{kg}, 0.05 \mathrm{mg} / \mathrm{kg}$ for hexachloren. The area of tugai woods and saksaul bushes deceased by 2 million hectares. Significant aridization of the climate was observed, winter became colder by $5-6^{\circ} \mathrm{C}$, summer temperature increased by $2-3{ }^{\circ} \mathrm{C}$, the number of days with salt-dust storms that are caused by low atmospheric pressure increased nearly two times. The number of bird species decreased from 319 at the beginning of the 1950s to 169 at the end of the 1970s, and to around 100 in the 1990s. Out of 70 mammals species previously inhabiting the estuary of Syr Darya only 26 (mainly rodents) remain. In the Aral Sea region, the number of cases of enteric fever increased 30 times, jaundice 7 times, morbidity by tuberculosis and cancer exceeds the mean average for the CIS by 15 times.

It should be noted that the arid Aral Sea area plays a role of furthering the 
desertification and vegetation degradation in adjacent territories. Degradation of vegetation occurs practically all over the Aral Sea basin, and is caused by the salinization of soils resulting from sewage-farming and salt-dust storms, the number of which have increased with dangerous frequency.

\section{Caspian Sea Region}

Extremely high technogenic stresses led to irreversible consequences for the Caspian region. The main form of pollution is associated with the exploitation of oil and gas deposits of which there are more than 100. Among them the Tengiz oil deposits are the most significant, but its exploitation is difficult and dangerous due to high oil pressures, high sulfur content up to $20 \%$ and the fact that the oil- bearing layers are located very deep below ground surface.

At present, as a result of mining, processing and transportation of uranium ore, there is an unfavorable radioactive situation in the Mangistau area. A large amount of low level radioactive oil waste has contaminated soil of about $10,000 \mathrm{~m}^{3}$ with radioactivity. In addition, there are nearly 540 tons of wasted oil pipes from oil mining enterprises. Burial of uranium radioactive waste with a mass up to 50,000 tons is being undertaken with the out of date technology and in the trenches without proper hydroisolation. A certain anxiety is also caused by the level of radiation on the territory of Galit structure, Azgir settlement of Atyrau region. Nine Cavities with the general volume of 1,200 thousand cubic meters appeared as a result of underground atomic tests. At present 5 cavities out of 9 are filled with salted solution.

Industrial development of other districts of Western Kazakhstan (Aktubinsk, Western Kazakhstan districts) caused water, air and soil pollution, from industrial emissions, such as oil products phenols and heavy metals. The ecological situation is especially hazardous in the region of Karachagnac oil and gas condensate complex. These problems are enhanced by the rise of water level of the Caspian Sea and degradation of coastal biocenoses. Some academic institutions investigated ecological situation in the region, reasoned on the rise of water level, and examined the coastal line of the Caspian Sea. Remote sensing monitoring is used there. Unless sufficient measures to combat the rising waters, the water will continue to rise over the next few years, threatening the future of 30 oil and gas deposits, 700 kilometers of roads, $300 \mathrm{~km}$ of railways and 1,700 
$\mathrm{km}$ of pipelines and power transmission lines in Mangistau and neighboring Atyrau oblast, they warn.

\section{Central Kazakhstan}

Degradation of environment in this region has been caused by the exploitation of coal deposits and emissions from metallurgical plants. Every year in Kazakhstan 1.5 billion ton of hard mineral materials are mined, from which 534 million tons are used in metallurgy. Only 4-5\% of the total processed volume is turned into the product and the remainder is removed to disposal area. The level of recycling of the remaining materials is very low: in nonferrous metallurgy; $5.6 \%$, in ferrous; $3.3 \%$ and in the coal industry; $5.2 \%$. About 16 billion tons of hard waste material have been currently accumulated in Kazakhstan. An evaluation of industrial hard waste is shown in Table 3. If the present level of technology and total volume of production of raw materials remain constant then the volume of hard waste will double by the year 2000 .

Table 3 Industrial Hard Wastes in Kazakhstan (1990)

\begin{tabular}{lcccc} 
& & \multicolumn{3}{c}{ unit : $1,000,000$ ton } \\
\hline & & Among them \\
\cline { 3 - 5 } \multicolumn{1}{c}{ Index } & Total & $\begin{array}{c}\text { nonferrous } \\
\text { metallurgy }\end{array}$ & $\begin{array}{c}\text { ferrousc } \\
\text { metal }\end{array}$ & $\begin{array}{c}\text { coal } \\
\text { industry }\end{array}$ \\
\hline $\begin{array}{l}\text { Aggregate volume of mining } \\
\text { of rock }\end{array}$ & 746 & 275 & 259 & 212 \\
$\quad$ Among them & & & & \\
\hline $\begin{array}{l}\text { Mineral wealth } \\
\begin{array}{l}\text { Overburden and heading rock } \\
\text { Tailings of enrichment }\end{array}\end{array}$ & 498 & 210 & 206 & 130 \\
$\quad$ Slag (metallurgy, ash-slag) & 79.4 & 55.2 & 19 & 5.2 \\
\hline
\end{tabular}

Air pollution from major industrial installations is another problem. The Karaganda metallurgical plant discharges into the atmosphere 700 tons of sulfide gas daily. Also, blast furnace gas with different compounds such as arsenic, phosphorus, antimony, lead, mercury and rare metals are being discharged into the atmosphere. The Ekibastuz power stations, which are working on low quality coal annually emit millions of tons of dust (caused by a high fly ash content of 
$40 \%$ ) which spreads over a vast territory.

\section{Semipalatinsk}

Kazakhstan is one of few countries which have suffered the terrible consequences of nuclear weapons testing ${ }^{4}$. The testing site at Semipalatinsk were in operation for about 42 years from 1949 to 1991. A total of 401 atomic bombs were exploded at underground level and in the atmosphere, of which 118 were atmospheric tests. It was not only at Semipalatinsk but also at many other areas of Kazakhstan where there were nuclear detonations, among them Azgir is in a dangerous situation. Every testing was kept absolutely secret. The people who lived in the area were not informed of what was happening. Approximately, 250,000 people lived in close proximity. Only 10,000, however, were examined for radiation. Evidence shows that it has resulted significant harmful effects on the health of people and ecology. The combination of all the tests result equals the severity of the Chernobyl catastrophe.

An anti-nuclear movement came into existence in response to a radioactive gas release from the test site on February 12 and 17, 1989, and all people of Kazakhstan came forward to demand the removal of nuclear weapons from their territory. The President and the Parliament of Kazakhstan accepted their demand, hence in the course of 1991 nuclear testing at the Semipalatinsk site was banned and rehabilitation of the site began following a presidential decree issued at the end of August 1991.

The main sources of radioactive waste in Kazakhstan include: atomic explosions; uranium mining and processing enterprises; ore mining enterprises; raw materials characterized by higher natural radio nuclides; atomic energetic and research reactors; and branches of industry that use isotopic materials.

The most dangerous uranium mining enterprises contain the majority of the radioactive waste which amounts to 217.7 million tons with 221.5 thousand Curie of activity. Radioactive waste from other branches of industry (nonuranium) increased due to the intensive use of oil and gas deposits. In this sector radioactive waste amounts to 1.57 million tons with 519 Curie of activity.

4. U. Sultangazin: Test Limitation and Nuclear Weapons Control in Kazakhstan, Symposium on Challenges for Peace and Security after the Cold War, Vienna, 1992. 
The waste from atomic blasts totals around 12 million tons with 12.9 million Curie out of which 6.5 million tons are due to underground explosions and will be long deposited in the molten rock. This waste is stored in rock cavities at the Semipalatinsk and Azgir sites. Surface radioactive waste at Semipalatinsk is kept on the alienated territory. In 1992, total radiation dose loading for 32 years was recorded in nuclear test site region. According to this evaluation the region was divided into four radiation risk zones: extreme ( $\mathrm{R}>100 \mathrm{rem})$, maximum (35rem $<\mathrm{R}<100 \mathrm{rem})$, high $(7 \mathrm{rem}<\mathrm{R}<35 \mathrm{rem})$, and minimum $(\mathrm{R}<7 \mathrm{rem})$, where $\mathrm{R}$ is the level of radiation ${ }^{5}$.

\section{Environmental Monitoring in Kazakhstan}

The Kazakh National Academy of Sciences has made considerable efforts toward solving the problem of natural resources usage in the Republic. Research and development activity of a number of institutes during the last decades covers a wide scientific spectrum of the dynamically changing nature of Kazakhstan. In spite of rich data obtained by the various institutes of the Academy of Sciences, it is difficult to obtain an accurate and comprehensive representation of the state of the environment and its trend during today's developmental course of Kazakhstan. Ground monitoring is carried out only in a limited number of areas and the extrapolation to other regions is to some degree of approximation. Therefore, a technique of remote sensing should be applied to compensate the shortcomings. In applying remote sensing, investigations through ground testing carried out by the institutes will be of great importance when deciphering aerospace photographs.

It should be noted that monitoring is an only one element of the environmental quality control system. The result of monitoring is a diagnosis of a state of environment in the territory, the result of modeling is a forecast of the dynamics of ecosystem development, while environmental control works out possible solutions using the diagnostic and forecasting data. Such a scheme seems to be the only reasonable approach for solving ecological problems at present stage.

The system of environmental monitoring for the territory of Kazakhstan is

5. M. Jarkenov, T. Saibekov: The Radiation Situation in Kazakhstan and the Safety Problem, Report of the Ministry of Ecology and Biological Resources, Almaty, 1994 (in Russian). 
projected in Figure 2 as a set of instruments oriented to solving concrete problems. For example, following two items are being highlighted for atmospheric problems ${ }^{6}$ :

*dust storms in the Aral Sea region, when million tons of salt are spread over a vast territory causing its desertification;

*urban air pollution spreading from gaseous source including the accidental emissions of pollutants;

We also developed concrete tasks for other media. Work on the complex analysis, using on mathematical models, is underway. Information technology in the form of data bases, transmission nets, interfaces and others is an integrating factor for the whole system. Information obtained at three levels (space, air, and ground) passes through the following stages: data acquisition, transmission, reception and primary data processing, archivation and the solution of applied problems. The project envisages accomplishing tasks of all stages. Space observations should be provided by satellites of the type NOAA, RESURS, Landsat and SPOT. Air observations are to be carried out on flying laboratories. Surface- based observations have been primarily conducted on the testing ground in the Aral Sea and in the neighborhoods of Almaty. Several satellite nets of data transfer exist: Planate-C, Dracon, Kurier, Horisont. The station of receiving and processing of space information has started its operation at the Institute of Space Research in Almaty and receives information from NOAA satellite. It develops systems of ecological monitoring of the Aral Sea and adjacent territories. In the future the data from the surface stations should be transferred by relay net into regional centers. All the information should be stored in the distributed data base for archivation. We hope that this base will be the main source for solving economical and ecological problems in Kazakhstan.

6. E. Zakarin, V. Kramar, V. Neshadim, U. Sultangazin: The TOPAZ programme system as the City Air Pollution System Model/Air Pollution Modeling and Its Applications, Proc. of the WMO Intern. Conference, Volume 2, Leningrad, 1987, pp. 303-310. 